\title{
Securitization of mortgage debt, domestic lending, and international risk sharing
}

\author{
Hoffmann, Mathias ; Nitschka, Thomas
}

\begin{abstract}
Securitization makes mortgage-related risks internationally tradeable and thus contributes considerably to the international diversification of macroeconomic risk: in the years 2003-2008, the increase in international cross-holdings of securitized mortgage debt has lowered industrialized countries' conditional consumption volatility (relative to the United States) by about 10-15 percentage points. We turn to the role of domestic credit in explaining this result. Domestic credit leads to better international risk sharing only if debt is securitized and traded internationally. Conversely, the risk-sharing benefits from securitization seem to evaporate if credit dries up - as it did in the recent financial crisis.La titrisation fait que les risques attachés aux hypothèques peuvent être transigés internationalement. Voilà qui contribue de manière significative à la diversification internationale des risques macroéconomiques : dans les années 2003-2008, l'accroissement dans la dette hypothécaire titrisée détenue dans d'autres pays a réduit la volatilité de la consommation relative (par rapport aux États-Unis) des pays industrialisés de 10-15 points de pourcentage. On examine le rôle du crédit domestique dans l'explication de ce résultat. On montre que le crédit domestique entraîne un meilleur partage international du risque seulement si la dette est titrisée et négociée internationalement. A contrario, les avantages de la titrisation semblent s'évaporer si le crédit s'assèche - comme ce fut le cas dans la récente crise financière.
\end{abstract}

DOI: https://doi.org/10.1111/j.1540-5982.2012.01701.x

Posted at the Zurich Open Repository and Archive, University of Zurich

ZORA URL: https://doi.org/10.5167/uzh-63215

Journal Article

Accepted Version

Originally published at:

Hoffmann, Mathias; Nitschka, Thomas (2012). Securitization of mortgage debt, domestic lending, and international risk sharing. Canadian Journal of Economics / Revue Canadienne d'Economique, 45(2):493-508.

DOI: https://doi.org/10.1111/j.1540-5982.2012.01701.x 


\title{
Securitization of Mortgage Debt, Domestic Lending and International Risk Sharing ${ }^{1}$
}

\author{
Mathias Hoffmann ${ }^{2}$ \\ Thomas Nitschka \\ University of Zurich \\ Swiss National Bank \\ Final version, October 2011.To appear in Canadian Journal of \\ Economics, vol 45 (1), Spring 2012.
}

\footnotetext{
${ }^{1}$ An earlier version of this paper was circulated under the title Home Bias: Asset Prices, Securitization of Mortgage Debt and International Risk Sharing. We have benefited from remarks by seminar participants at the ZEW-Bundesbank Workshop on Housing and Asset Markets, the 3rd Zurich Macroeconomics and Finance Conference, at University of Stirling, University of Basel, the CESifo Money, Macro and International Finance Conference, the Macroeconomic Research Meeting 2009 in Tübingen, the Royal Economic Society Conference 2009, the ESSET 2009 in Gerzensee and the CEPR-National Bank of Belgium-ECARES workshop on International Risk Sharing. In particular, we would like to thank Philipp Harms, Yin-Wong Cheung and Bent Sørensen for their detailed discussions of the paper. We are also grateful to Sascha Becker, Jean Imbs and Philip Lane for useful suggestions. Any errors remain entirely our own.

${ }^{2}$ Mathias Hoffmann (corresponding author) is at University of Zurich, Department of Economics, Chair of International Trade and Finance, Zürichbergstrasse 14, CH-8032 Zurich, Switzerland. Phone: $++41-44-6345258$. He is also affiliated with CESifo Munich. Thomas Nitschka is at Swiss National Bank, Börsenstrasse 15, P.O. Box, CH 8022 Zürich, Switzerland.

E-Mail: mathias.hoffmann@econ.uzh.ch and thomas.nitschka@snb.ch
} 


\begin{abstract}
Securitization makes mortgage-related risks internationally tradeable and thus contributes considerably to the international diversification of macroeconomic risk: in the years 2003-2008, the increase in international cross holdings of securitized mortgage debt has lowered industrialized countries' conditional consumption volatility (relative to the United States) by about 10-15 percentage points. We turn to the role of domestic credit in explaining this result. Domestic credit leads to better international risk sharing only if debt is securitized and traded internationally. Conversely, the risk-sharing benefits from securitization seem to evaporate if credit dries up - as it did in the recent financial crisis.

KEYWORDS: FINANCIAL GLOBALIZATION, INTERNATIONAL RISK SHARING, HOME BIAS, SECURITIZATION, MORTGAGE MARKETS, ASSET PRICES, INTERNATIONAL BUSINESS CYCLES

JEL CLASSIFICATION: F 36, F 41, G15, G21
\end{abstract}




\section{Introduction}

The securitization of mortgage-related debt has played a major role in the emergence and proliferation of the current financial crisis (see Brunnermeier (2009) for a detailed account). Understandably, this has led to widespread skepticism with respect to the usefulness of such instruments for an efficient allocation of macroeconomic risk. From the current experience it seems obvious that the repackaging of mortgage debt in mortgage-backed securities (MBS) can have enormous aggregate costs, ${ }^{1}$ but to date no empirical account of the potential macroeconomic benefits of these instruments exists.

In this paper we contribute to filling this gap by exploring the impact that the increasing use of mortgage securitization has had on the international diversification of macroeconomic risk. From a theoretical point of view, one may expect that the impact of mortgage securitization could be large. Mortgage markets are internationally far less integrated than say equity or bond markets. Residential real estate is largely domestically financed in most economies, making fluctuations in the value of housing and the quality of mortgage debt a major background risk from the perspective of an individual country. Securitization can help diversify such risks internationally because it makes mortgage-debt internationally tradeable.

Indeed, we find that the increase in international cross holdings of securitized mortgage debt from 2003 to 2008 has lowered the sensitivity of consumption to a country-specific one percent growth shock by about 10-15 percentage points. In examining the quantitative impact of securitization on international consumption risk sharing, we also attempt to shed light on some key elements of the mechanism through which risk is shared. There 
is by now a large literature emphasizing the role of increased international asset holdings for improvements in international risk sharing. It would at first seem that increased securitization is just another instance of this globalization in international asset positions. We argue it is more: the growth in securitized debt issuance in the last decade was driven largely by mortgage debt and as we have argued, mortgage debt is issued largely by domestic banks to domestic households. While increased domestic lending can provide better risk sharing between banks and households within a country, it is not clear a priori why purely domestic credit growth should contribute to better consumption risk sharing between countries. We show that the effect of domestic credit on international risk sharing depends on the extent of securitization. Taken by itself, we find no effect of domestic credit on international risk sharing but the effect is very strong, once credit is interacted with securitization. Our interpretation of these findings is that securitization increases the international risk sharing benefits from domestic credit by dispersing domestic credit risk internationally. ${ }^{2}$ This is our main result, which is also robust to controlling for the simultaneous growth in direct international cross-holdings of other financial assets.

If securitization carries benefits in terms of better international risk sharing, this inevitably raises the question whether the costs inflicted by a major downturn such as the subprime crisis could not still outweigh the potential welfare benefits of better international risk sharing by an order of magnitude. Securitization may well facilitate risk sharing in tranquil times, but it might actually make things worse in a crisis. Our results also shed some light on this issue: because the interaction between domestic credit and securitization matters for international risk sharing, there will be less or even no risk sharing benefits from securitization once credit declines sharply as it 
did in the recent financial crisis. Indeed, our estimates suggest a huge drop in international risk sharing during 2007/08.

Finally, in interpreting our results, it is important to bear in mind that the bulk of the international trade in mortgage backed securities before the recent financial crisis was unidirectional, with the United States predominantly selling and the rest of the industrialized world buying these assets a stylized fact that we document in detail in the remainder of the paper. Our findings therefore could also be read as implying that industrialized countries' consumption fluctuations have become more aligned with US shocks in the run-up to the subprime crisis. While perfectly consistent with improved risk sharing, this could mean that the risk sharing benefits may largely have been reaped by the US itself, which may thus have been able to offload to other countries a significant fraction of the risk associated with its domestic mortgage debt. Specifically, the reduced-form evidence in this paper is consistent with the possibility that this international trade in MBS may have contributed to 'exporting' what had started as a domestic US financial crisis. While we explicitly acknowledge these points, we also note that the global spread of the crisis is not in itself evidence against potential risk sharing benefits from trade in mortgage-backed securities: we just do not know the counterfactual, i.e. how much worse the crisis for the US could possibly have been if some of the burden had not been shared by other countries through the international trade in these securities.

The paper is structured as follows. In the next section, we present our empirical framework. Section three presents our data set. Section four presents the bulk of our empirical results. Section five summarizes and concludes. 


\section{International Risk Sharing and the securitization of mortgage debt}

We measure consumption risk sharing through panel regressions of the form

$$
\Delta \log \frac{C_{t}^{k}}{C_{t}^{*}}=\beta_{U}\left[\Delta \log \frac{G D P_{t}^{k}}{G D P_{t}^{*}}\right]+\varepsilon_{t}^{k}
$$

where $C_{t}^{k}$ is per capita consumption in country $k$ in period $t, G D P_{t}^{k}$ is the country's output per head and the asterisk denotes the international per capita average of the respective variable.

Regressions such as (1) have been widely used in empirical macroeconomics as a way to measure the incompleteness of financial markets. ${ }^{3}$ Specifically, we can think of the estimate of $\beta_{U}$ as measuring the amount of uninsured idiosyncratic output risk. At an empirical level, this interpretation is based on the stylized fact that, in panel data, $\beta_{U}$ is regularly between 0 and unity. Thus, $1-\beta_{U}$ can straightforwardly be associated with the share of the average country's idiosyncratic business cycle risk that gets shared via financial markets, whereas $\beta_{U}$ is the fraction of non-diversified idiosyncratic risk faced by the average country in the panel.

Early estimates of $\beta_{U}$ based on international data typically were in the range between 0.7 and 0.8 . Estimates based on more recent data are often found to be considerably lower, reflecting the effect of financial globalization on international risk sharing (see Sørensen et al. (2007), Artis and Hoffmann (2006)).

In this paper, we wish to explore to what extent $\beta_{U}$ varies across countries depending on the degree to which mortgage-related debt is securitized and traded internationally. Our basic tool will be panel regressions in which 
we parametrize the coefficient $\beta_{U}$ as a linear function of securitization and of other country- and time-varying controls, so that

$$
\beta_{U}^{k}(t)=\beta_{0}+\mathbf{z}_{t}^{k \prime} \beta_{z}
$$

where $\mathbf{z}_{t}^{k}$ is a vector containing time-varying and country-specific characteristics. We partition $\mathbf{z}_{t}^{k}$ into aggregate, $\mathbf{x}_{t}^{\prime}$, and (time-invariant) countryspecific characteristics, $\boldsymbol{v}^{k}$. In addition, we also allow for some characteristics to vary by country and time, $\mathbf{y}_{t}^{\prime k}$, so that $\mathbf{z}_{t}^{k \prime}=\left[\mathbf{x}_{t}^{\prime}, \boldsymbol{v}^{k \prime}, \mathbf{y}_{t}^{k \prime}\right]$. The equation we estimate is of the form

$$
\Delta \widetilde{c}_{t}^{k}=\beta_{0} \Delta \widetilde{g d p_{t}^{k}}+\mathbf{z}_{t}^{k \prime} \beta_{z} \Delta \widetilde{g d p_{t}^{k}}+\mathbf{y}_{t}^{k \prime} \gamma+\alpha+\delta^{k}+\tau_{t}+\varepsilon_{t}^{k}
$$

Here, and in the remainder of the paper, we use lower-case letters to denote logarithms and the tilde to denote idiosyncratic variables, so that, e.g., $\widetilde{\Delta c_{t}^{k}}=\Delta \log \left[C_{t}^{k} / C_{t}^{*}\right]$. The first two terms come from plugging the definition (2) into the basic risk sharing regression (1). Our estimation equation also includes country-fixed effects $\left(\delta^{k}\right)$ to allow for long-term cross-country differences in consumption growth rates that may be unrelated to imperfect risk sharing and a common time effect $\left(\tau_{t}\right)$ to allow for any additional crosssectional dependence that may not be controlled by our use of idiosyncratic growth rates. To avoid spurious estimates of the coefficient vector $\beta_{z}$ on the interaction terms, we would generally also need to include first-order terms of $\mathbf{z}_{t}^{k \prime}$. Note that in the particular specification this will not be necessary for all components of $\mathbf{z}_{t}^{k}$. The reason for this is that the time-variation in aggregate variables will be captured through the panel time-specific effects. Equally, as long as the country-specific characteristics are assumed to be time-invariant, these will be fully captured by the country fixed-effects. 
Hence, the specification above will include the first-order terms only for those components of $\mathbf{z}_{t}^{k}$, the characteristics $\mathbf{y}_{t}^{k}$, that vary across countries and time (such as e.g. our indicator of securitization). ${ }^{4}$

In our final specification, the vector $\mathbf{z}_{t}^{k}$ will include a measure for mortgage securitization, a measure of lending and the interaction between the two, as well as a number of controls, such as international asset positions so that

$\beta_{U}^{k}(t)=\beta_{0}+\beta_{1} S E C_{t}^{k}+\beta_{2}\left[\frac{\text { Credit }}{G D P}\right]_{t}^{k}+\beta_{3} S E C_{t}^{k} \times\left[\frac{\text { Credit }}{G D P}\right]_{t}^{k}+$ controls $^{\prime} \boldsymbol{\beta}_{\text {ctrl }}$

We use two quantitative measures that we denote with $S E C_{t}^{X, k}$ where the $X$ is a stand-in for the specific measure. In the next section, we describe in detail how the two measures are constructed.

\section{Data}

\subsection{Measuring the Securitization of Mortgage Debt}

Quantitative data on the actual extent to which mortgage debt is securitized is not available for many countries. One exception is the US, for which data on international cross-holdings of asset-backed securities (ABS) are available on an annual basis from 2003 to 2008 from the Report on Foreign Portfolio Holdings of U.S. Securities and the respective issues of the Report on U.S. Portfolio Holdings of Foreign Securities by the US Department of the Treasury Office of International Affairs. These data are part of the Treasury International Capital (TIC) system and we refer to them as TIC data. ${ }^{5}$

Based on these data, we calculate gross and net country ABS holdings. Our measure of gross holdings is 


$$
S E C_{t}^{G A B, k}=\frac{A B S_{t}^{k, U S}+A B S_{t}^{U S, k}}{G D P_{t}^{k}+G D P_{t}^{U S}}
$$

where $A B S^{k, U S}$ denotes country $k$ holdings of US-collateralized ABS and $A B S^{U S, k}$ the respective holdings of the US in country $k$ and the acronym $G A B$ stands for 'Gross Asset-Backed' securities. This first quantitative measure focuses on (cumulated) bilateral trade in asset backed securities. We normalize with the joint GDP of both countries to control for size differences, which is analogous to the bilateral openness measure commonly used in the trade literature. The second measure is constructed in the same way, except that now we focus on the net position of country $k$ with the US:

$$
S E C_{t}^{N A B, k}=\frac{A B S_{t}^{k, U S}-A B S_{t}^{U S, k}}{G D P_{t}^{k}+G D P_{t}^{U S}}
$$

where $N A B$ stands for 'Net Asset-Backed' securities. Ideally, we would like to have gross and net positions for each country against the rest-of-theworld. Such data are, however, not available and any attempt to calculate them would require very strong assumptions. The measures here effectively treat the United States as rest-of-the-world. This assumption is not overly restrictive, though: in our sample of countries, the US accounted for almost 90 percent of the value of outstanding ABS in 2003 and still for more than three quarters in $2008 .^{6}$

\section{[TABLE 1 ABOUT HERE]}

Table 1 provides some descriptives for the TIC data set. Panel A reports numbers relative to home country GDP, Panel B as a share of joint (US +home) GDP at current exchange rates. Both panels give largely the same message: first, it is apparent that international positions in $A B S$ have 
increased considerably between 2003 and 2008, both in gross and net terms. Average gross positions with the US have more than doubled from 1.65 percent of home GDP to 3.33. The increase is in the same order of magnitude when measured relative to joint GDP, with cross-holdings virtually doubling from 0.12 percent of joint GDP to 0.26 . There is a lot of variation across countries, though. Whereas in both 2003 and 2008, some countries had virtually no cross-holdings in ABS with the US, for other countries these positions amount to more than 10 percent of home GDP (or 0.8 of joint GDP). The table also shows that most international trade in mortgage-backed securities is one-way - from the US to other countries: average net positions are not much smaller than gross positions reflecting the fact that most countries have high average MBS assets in the United States but virtually no liabilities vis-à-vis that country.

\section{[FIGURE 1 ABOUT HERE]}

Figure 1 presents the cross-sectional average of the gross positions over time. We see a very steep increase in ABS holdings until 2007 and a pronounced fall in these holdings in 2008, the latter clearly the effect of the

subprime crisis. A very similar trend is discernible from the net ABS positions (not shown), which again reflects the fact that the United States are a big net issuer of securitized debt, so that international gross positions, to a large extent, reflect the negative US net position in these assets. ${ }^{7}$

\subsection{Country sample, output and consumption data}

Our sample comprises the following 14 countries: Australia, Belgium, 
Canada, Denmark, France, Germany, Italy, Japan, the Netherlands, Spain, Sweden, Switzerland, United Kingdom and the United States. We obtain annual, real consumption p.c. and real GDP p.c. from the IMF's Financial Statistics. Consumption and GDP are deflated with the respective countries' CPI and population figures.

\section{Results}

\subsection{Baseline results}

Table 2 displays our first results. In column I we present the results form the baseline regression

$$
\Delta \widetilde{c}_{t}^{k}=\beta_{0} \Delta \widetilde{g d p}_{t}^{k}+\beta_{1} S E C_{t}^{X, k} \times \Delta \widetilde{g d p_{t}^{k}}+\gamma_{1} S E C_{t}^{X, k}+\alpha+\delta^{k}+\tau_{t}+\varepsilon_{t}^{k}
$$

Robust t-statistics appear below the estimates in parentheses. ${ }^{8}$ Panel A is for the gross measure, $S E C^{G A B}$, Panel B for the net measure $S E C^{N A B} .9$

The coefficient on $S E C$ is significant at the 5\%-level for both measures. The effect is also economically important: the coefficients on $S E C^{G A B}$ and $S E C^{N A B}$ are normalized to reflect a typical (ten basis point) change in these variables (which are expressed as gross or net holdings relative to joint GDP). ${ }^{10}$ Hence, an estimate of $\beta_{1}$ of around -0.1 implies that a one basis point increase in $S E C^{G A B}$ or $S E C^{N A B}$ is associated with an almost one percentage point improvement in risk sharing. As is apparent from Table 1, over the period 2003-08, $S E C^{G A B}$ for the average country has increased by 14 basis points, from 0.12 to 0.26 percent of joint GDP, implying that cross-holdings of securitized assets should have contributed to an average increase in bilateral risk sharing with the US (decrease in $\beta_{U}^{k}(t)$ ) of around 
14 percentage points.

[TABLE 2 ABOUT HERE]

Columns II and III provide a set of general robustness checks: in column II, we include time fixed effects in the interaction with $\widetilde{\Delta g d p}$ to control for any trend that is common across countries and that might be correlated with securitization. In column III, we remove the country-specific mean from our securitization measure to control for unobservable or omitted (timeinvariant) country-characteristics in the interaction term with $\widetilde{\Delta g d p_{t}}$. Both of these changes in specification leave our estimated coefficients quite stable and significantly negative. ${ }^{11}$

These are our baseline results: securitization of mortgage debt seems associated with better risk sharing at the international level. That raises the question 'why?'. We argue that securitization allows the better diversification of domestic credit risk, notably of the risk associated with mortgage debt. This implies that securitization should impact international risk sharing through its impact on domestic lending. We explore this possibility next. Before doing so, however, we show that securitization is not just another form of financial globalization and we present some robustness checks.

\subsection{Securitization and international financial integration}

Securitization of mortgage related debt seems to improve international risk sharing, which suggests that it is an important aspect of financial globalization. However, securitization could just be another facet of the secular growth in international gross asset holdings that we have seen since the early/mid 1990s (see Lane and Milesi-Ferretti (2003, 2007)). Sørensen 
et al. (2007) and Artis and Hoffmann (2006) document that the increase in cross-border asset holdings is echoed in improved international consumption risk sharing. Since the increase in gross foreign asset holdings worldwide coincides with the period at which securitization has been introduced in various countries in our sample, our securitization indicator could just pick up this trend in financial globalization. Not so: we parametrize risk sharing as a function of a (country-specific) financial globalization trend

$$
\beta_{U}^{k}(t)=\beta_{0}+\beta_{1} S E C_{t}^{X, k}+\beta_{2} g f a_{t}^{k}
$$

where $t$ denotes a time trend and $g f a_{t}^{k}=\frac{\left(F A_{t}^{k}+F L_{t}^{k}\right)}{G D P_{t}^{k}}$ the average gross foreign asset positions of country $k$ relative to its GDP with $F A_{t}^{k}\left(F L_{t}^{k}\right)$ denoting foreign assets (liabilities) of country $k$ at time $t$. Lane and MilesiFerretti $(2003,2007)$ propose $g f a_{t}^{k}$ as a measure of the trend in financial integration. We use their updated data set here which stretches till the end of 2007. For the last year of our sample, 2008, we extrapolate $g f a_{t}^{k}$ using a fourth-order polynomial in $t$ that we previously fitted to each country's asset position for the period up to 2007. Table 3 summarizes the results: the coefficient on $S E C_{t}^{X, k}$ remains stable and significant in both the net and gross specifications: securitization improves international risk sharing even if we control for the country-specific trend induced by international cross-holdings of other financial assets.

[TABLE 3 ABOUT HERE] 


\subsection{The channel: international trade in securitized debt and do- mestic lending}

The exact mechanisms through which securitization may impact on international consumption patterns are likely to be complex and sensitive to the institutional framework in each individual country. It is beyond the scope of this paper to offer a theoretical model that discusses these issues. However, our results show that the degree to which securitized debt is traded across national boundaries has a strong bearing on international risk sharing. We now turn to what we believe to be the direct consequences of the increased tradeability of mortgage debt for bank lending behavior: by selling mortgage debt, banks can reduce their exposure to local business cycle and housing market conditions. This puts them into a position to keep on lending even in recessions and when credit market conditions are tight, thus allowing households to effectively share consumption risk through increased borrowing. The empirical relevance of this transmission mechanism for the United States has been demonstrated by Loutskina and Strahan (2009) who show that securitization increased bank lending which may in turn have been beneficial to risk sharing. Here, we examine whether the interaction between domestic credit and international trade in securitized assets can help explain why securitization increases consumption risk sharing between countries.

[TABLE 4 ABOUT HERE]

In the first panel of Table 4, we specify international risk sharing as a 
function of domestic credit

$$
\beta_{U}^{k}(t)=\beta_{0}+\beta_{1}\left[\frac{\text { credit }}{G D P}\right]_{t}^{k}
$$

The coefficient is insignificant and positive, suggesting that domestic credit alone may not necessarily improve risk sharing. The next panel of Table 4 reports the results of a horse race between credit and our securitization indicators, i.e. a specification of the form

$$
\beta_{U}^{k}(t)=\beta_{0}+\beta_{1}\left[\frac{\text { credit }}{G D P}\right]_{t}^{k}+\beta_{2} S E C_{t}^{X, k}
$$

where, again, $X=G A B, N A B$ in turn. The coefficient on securitization is negative in all cases and significant, whereas the coefficient on credit remains positive. Hence, more domestic credit per se is not generally associated with better international consumption risk sharing, whereas international cross-holdings of securitized domestic debt are. Our interpretation of these findings is that domestic lending may not necessarily lead to better international risk sharing unless a part of this domestic credit risk is eventually sold internationally. Securitization should make domestic debt (in particular mortgages) more easily tradeable across national borders, thus translating increased domestic lending into better risk sharing between countries. ${ }^{12}$

This interpretation is supported by the results of a specification for $\beta_{U}(t)$ in which we include an interaction term between domestic credit and securitization:

$$
\beta_{U}^{k}(t)=\beta_{0}+\beta_{1}\left[\frac{\text { credit }}{G D P}\right]_{t}^{k}+\beta_{2} S E C_{t}^{k}+\beta_{3} \times\left[\frac{\text { credit }}{G D P}\right]_{t}^{k} \times S E C_{t}^{X, k}+\beta_{4} t
$$

Results are in the last rows of each panel in Table 4. The coefficient on the 
interaction between credit and securitization is negative and significant for both the gross and the net measures. This suggests that securitization has a stronger effect on international risk sharing when credit is abundant. Credit alone, however, does not appear to impact on international risk sharing. ${ }^{13}$

\subsection{Robustness}

We briefly summarize a number of robustness checks that we conducted and of which detailed results are available in a Technical Appendix on the web: ${ }^{14}$ first, we checked whether our results are driven by outliers. To this end, we parametrized the baseline regressions in Table 1 in terms of $\log \left(1+S E C_{t}^{X, k}\right)$ instead of $S E C_{t}^{X, k}$. This somewhat lowered the statistical significance of our results but did not affect their overall flavour: there is an economically significant link between securitization and risk sharing. Second, we normalized international gross and net holdings of securitzed assets with country GDP rather than the sum of US and country GDP. Again, this does not change the basic result. ${ }^{15}$

As a last exercise we checked whether the importance of the interaction between credit and securitization is driven by cyclical variation in credit or by country-specific (but time invariant) differences in the ratio of credit to GDP. To this end, we used the country-specific sample means of credit/GDP in the regressions in Table 4. We find that these country-specific differences are important, but that there also seems to be a a role for the cylical component in credit. We turn to this point in more detail in the next subsection. 


\subsection{Securitization and international risk sharing in the recent financial crisis}

Our finding that the interaction between domestic credit and international trade in securitized assets is important for international risk sharing has interesting implications for the role of securitization during the recent financial crisis. Specifically, if credit declines sharply - as it did during the recent crisis - the results in Table 4 might lead us to expect that the impact of securitization on international risk sharing should have declined.

\section{[FIGURE 2 ABOUT HERE]}

To capture such time variation in international risk sharing, we run a sequence of cross-sectional regressions for the years $t=2005 \ldots 2008:^{16}$

$$
\Delta \widetilde{c}_{t}^{k}=\beta_{0}(t) \Delta \widetilde{g d p}_{t}^{k}+\beta_{1}(t) \times S E C_{t-1}^{G A B, k} \times \Delta \widetilde{g d p}_{t}^{k}+\tau_{t}+\varepsilon_{t}^{k}
$$

Figure 2 plots the sequence of coefficients $\beta_{1}(t)$ on the interaction between securitization and idiosyncratic GDP growth. The coefficient becomes more and more negative in the years before 2008, signaling an increasing contribution of securitization to risk sharing. In the crisis year 2008, however, it actually becomes positive (though it is very close to zero). Note that each of the cross-sectional estimates of $\beta_{1}(t)$ for $t=2005 . .2008$ is derived from very few observations. The asymptotic standard error bands provided in the figure - which are already relatively wide - therefore most likely underestimate the true uncertainty surrounding these estimates. We therefore think of figure 2 as a first look at this issue. This first look, however, is broadly consistent with our conjecture: securitization has had a procyclical effect on 
international risk sharing - while it tended to improve risk sharing in the boom years, this positive effect practically vanished in the crisis.

\section{Conclusions}

We find that international cross-holdings of securitized debt is associated with better international consumption risk sharing. The effect is large: in the years before the recent financial crisis, the increase in international cross holdings of securitized mortgage debt has lowered relative consumption growth volatility (conditional on a country's typical output growth shock vis-à-vis the United States) by about 10-15 percentage points. We find that this result is robust to a range of controls for other aspects of financial globalization.

What can explain this large effect? We argue that it is the interaction between the availability of domestic credit and securitization. While higher domestic credit is not unconditionally very strongly correlated with more international risk sharing, we find that it is among countries with higher international positions in securitized debt. This suggests that securitization helps spread the risks associated with domestic credit growth internationally. This seems true in particular in the one segment of the credit market that was previously the most internationally segmented: mortgages. Conversely, our results also suggest that the risk sharing benefits of securitization are likely to be contingent on the availability of domestic credit: we find no risk sharing benefits from securitization during the subprime crisis, when the stock of outstanding domestic credit fell dramatically. 


\section{References}

Artis, M. J. and Hoffmann, M. (2006). The home bias and capital income flows between countries and regions. CEPR Discussion Papers 5691, C.E.P.R. Discussion Papers.

Asdrubali, P., Sørensen, B. E., and Yosha, O. (1996). Channels of interstate risk sharing: United States 1963-1990. Quarterly Journal of Economics, 111 (4):1081-1110.

Brunnermeier, M. K. (2009). Deciphering the liquidity and credit crunch 2007-2008. Journal of Economic Perspectives, 23(1):77-100.

Crucini, M. C. (1999). On international and national dimensions of risk sharing. Review of Economics and Statistics, 81 (1):73-84.

Demyanyk, Y. and van Hemert, O. (2008). Understanding the subprime mortgage crisis. Proceedings of the Federal Reserve Bank of Chicago, (May):171-192.

Keys, B. J., Mukherjee, T., Seru, A., and Vig, V. (2009). Financial regulation and securitization: Evidence from subprime loans. Journal of Monetary Economics, 56(5):700-720.

Lane, P. R. and Milesi-Ferretti, G. M. (2003). International financial integration. CEPR Discussion Papers 3769, C.E.P.R. Discussion Papers.

Lane, P. R. and Milesi-Ferretti, G. M. (2007). The external wealth of nations mark II: Revised and extended estimates of foreign assets and liabilities, 1970-2004. Journal of International Economics, 73(2):223-250.

Loutskina, E. and Strahan, P. B. (2009). Securitization and the declining 
impact of bank finance on loan supply: Evidence from mortgage originations. Journal of Finance, 64(2):861-889.

Mian, A. and Sufi, A. (2009). The consequences of mortgage credit expansion: Evidence from the 2007 mortgage default crisis. Quarterly Journal of Economics, 124(4):1449-1496.

Newey, W. K. and West, K. D. (1987). A simple, positive semi-definite, heteroskedasticity and autocorrelation consistent covariance matrix. Econometrica, 55(3):703-08.

Ozer-Balli, H. and Sørensen, B. E. (2010). Interaction effects in econometrics. Technical report, CEPR Discussion Paper no 7929.

Petersen, M. A. (2009). Estimating standard errors in finance panel data sets: Comparing approaches. Review of Financial Studies, 22 (1):435-80.

Sørensen, B. E., Wu, Y.-T., Yosha, O., and Zhu, Y. (2007). Home bias and international risk sharing: Twin puzzles separated at birth. Journal of International Money and Finance, 26:587-605.

Sørensen, B. E. and Yosha, O. (1998). International risk sharing and European monetary unification. Journal of International Economics, 45(2):211-238.

\section{Notes}

\footnotetext{
${ }^{1}$ See Keys et al. (2009) and Mian and Sufi (2009) for detailed empirical accounts of how the originate-to-distribute model has led to moral hazard and lax screening in the run-up to the subprime crisis. Demyanyk and van Hemert (2008) argue that even though loan quality in the U.S mortgage market deteriorated long before the crisis, securitizers were to some extent aware of this.

${ }^{2}$ Our findings constitute a corroboration of the results by Loutskina and Strahan (2009) in an international context. Our focus here is broader, though, in that we also look at the
} 
implications of securitization for consumption risk sharing. This aspect is absent from their study.

${ }^{3}$ In the form in which we use them here they go back (at least) to Asdrubali et al. (1996) and Sørensen and Yosha (1998). Crucini (1999) uses a very similar setup and also provides a simple theoretical model in which the coefficient $\beta_{U}$ can directly be interpreted as the share of claims to domestic output in the country's wealth portfolio.

${ }^{4}$ Some papers in the empirical risk sharing literature use fixed and time effects, some do not. Our results are not sensitive to this.

${ }^{5}$ Unfortunately the TIC data do not allow us to directly distinguish between securitized mortgage debt and other securitized debt. However, mortgage debt very plausibly accounted for the lion's share of the international trade in securitized assets: of the 6911.4 billion dollar in ABS outstanding in the US at the end of 2008, more than 5000 were mortgage-backed. Data from the European Securitization Forum suggest that in Europe the share of mortgagebacked securities in the total volume of outstanding ABS is of a similar magnitude.

${ }^{6}$ We obtain data on outstanding ABS from the FED's Z1 Flow of Funds Accounts considering both private issuers as well as agency issued ABS backed by US collateral. We put this number in relation to the US dollar amount outstanding of ABS backed by other countries' collateral. The latter are obtained from the European Securitisation Forum Securitisation Data Reports and are freely available on the website of the Association for Financial Markets in Europe.

${ }^{7}$ We also constructed a de iure measure of securitization which allowed us to corroborate some of our results on a longer sample. We do not report these results here because the measure is very noisy and not conceptually comparable to our de facto measures here: it only gauges the legal facility with which it is possible for a country to issue mortgage-backed securities. It does not allow us to capture to which extent such assets are actually issued, let alone traded across national borders. It is, however, the latter aspect that we would expect to matter for international risk sharing. Details are available from a previous working paper version (Hoffmann and Nitschka (2008)).

${ }^{8}$ Throughout the paper, we use standard errors clustered by country. This procedure assumes errors to be uncorrelated across countries but allows each country to have different (and unknown) forms of serial correlation and heteroskedasticity. Petersen (2009) advocates clustering as a very efficient and robust way to estimate standard errors and shows that it will lead to more conservative estimates than (panel-adjusted) versions of e.g. the Newey and West (1987) method.

${ }^{9}$ Our empirical implementation of the risk sharing regression uses the United States as stand-in for the rest of the world, i.e. idiosyncratic consumption and idiosyncratic GDP growth are measured as $\Delta \widetilde{c}_{t}^{k}=\Delta c_{t}^{k}-\Delta c_{t}^{U S}$ and $\Delta \widetilde{g d p}_{t}^{k}=\Delta g d p_{t}^{k}-\Delta g d p_{t}^{U S}$. This choice would seem natural, since we only have bilateral cross-holdings of collateralized debt between the US and the other countries in our sample. We note that our results are not sensitive to whether we use the US or the world average as measure of $\Delta c^{*}$ and $\Delta g d p^{*}$.

${ }^{10} \mathrm{As}$ is apparent from the figure and from Table 1, the variation in $S E C^{G A B}$ and $S E C^{N A B}$ are in the order of magnitude of several tenths of one percent (ten basis points) of joint GDP. These numbers are numerically small because they are expressed relative to the sum of country $k$ and U.S. GDP and because the U.S. economy is by far the biggest economy in the sample. As the first part of Table 1 shows, from the point of view of the individual (non-U.S.) economies, however, the bilateral gross and net holdings are economically quite sizeable. In order to facilitate interpretation of our empirical specifications below, we normalize all coefficients on $S E C^{N A B}$ and $S E C^{G A B}$ by 1000 so that they reflect the marginal impact of a 'typical' change in these measures, i.e. in the order of magnitude of ten basis points.

${ }^{11}$ Specifically, de-meaning will also control for the importance of country-size differences, provided these are invariant or at least very persistent. The findings here therefore suggests that our results should be similar if we measure gross and net holdings of securitized debt as a fraction of home (instead of joint) GDP. We checked that this is indeed the case. See 
Ozer-Balli and Sørensen (2010) for a succinct guide to the interpretation of time- and crosssectionally demeaned interactions.

${ }^{12}$ We emphasize that this does not preclude the possibility that increased domestic lending may lead to better risk sharing between the households (and banks) within a country (see Loutskina and Strahan (2009)).

${ }^{13}$ Again we emphasize that this does not preclude the possibility that domestic credit may lead to unconditionally better risk sharing between the households (and banks) within a country.

${ }^{14}$ See $w w w . c j e . e c o n o m i c s . c a$

${ }^{15}$ Note that all the results reported in the paper and in which net and gross holdings are normalized by the sum of US and country GDP implicitly give higher weight to larger countries: our measures can be written as $S E C_{t}^{X, k}=\frac{X}{G D P_{t}^{k}+G D P_{t}^{U S}}=\frac{X}{G D P_{t}^{k}} \times \frac{G D P_{t}^{k}}{G D P_{t}^{k}+G D P_{t}^{U S}}$ where $X$ stands in turn for the gross and net position in terms of securitized assets. We believe that this weighting is reasonable: the estimated coefficient on the interaction between $S E C$ and idiosyncratic GDP growth tells us by how much securitization lowers the sensitivity of per capita consumption growth (relative to the US per capita average) to idiosyncratic output shocks for the average consumer in one of the countries' in our sample. Clearly, in answering this question, it makes sense to weight with country size.

${ }^{16}$ To control somewhat for the feedback that the crisis had on the valuation of securitized debt, this specification uses lagged values of $S E C$. Note that the coefficients on securitization remain stable if we use lagged $S E C$ in our panel-based specifications above. 


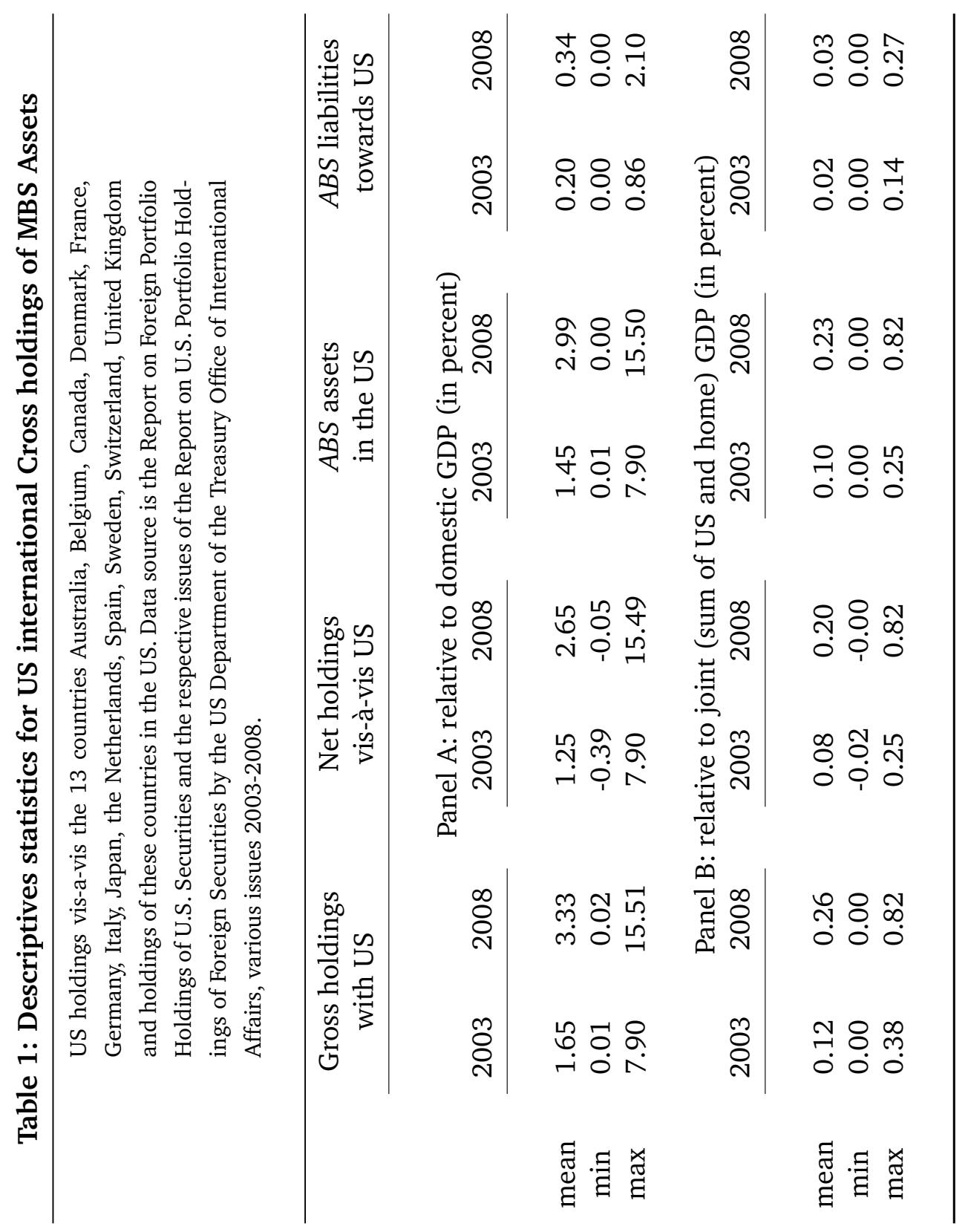




\section{Table 2: Securitization and international risk sharing}

The first column (I) of the table displays the estimates from our baseline risk sharing regression:

$$
\Delta \widetilde{c}_{t}^{k}=\beta_{0} \Delta \widetilde{g d p}_{t}^{k}+\beta_{1} S E C_{t}^{X, k} \times \Delta{\widetilde{g d p_{t}}}^{k}+\gamma_{1} S E C_{t}^{X, k}+\alpha+\delta^{k}+\tau_{t}+\varepsilon_{t}^{k}
$$

where $\Delta \widetilde{c}_{t}^{k}$ denotes idiosyncratic consumption growth, $\Delta \widetilde{g d p}_{t}^{k}$ idiosyncratic GDP growth and $S E C_{t}^{X, k}$ is one of our securitization measures $X=G A B, N A B$. Column (II) presents results of a specification that also includes a time fixed effect in the interaction with $\Delta \widetilde{g d p}_{t}^{k}$ (i.e. a set of regressors $\mathbf{1}_{t} \times \Delta{\widetilde{\Delta d p_{t}}}_{t}^{k}$ for $t=1 \ldots T$ where $\mathbf{1}_{t}$ is the time effect dummy that is unity for period $t$ and zeros otherwise) whereas column (III) presents the results for the case in which the country-k mean of $S E C_{t}^{X, k}$ is removed.

Robust t-statistics (clustered by country) are in parentheses below the estimates. Coefficients on $S E C^{G A B}$ and $S E C^{N A B}$ are normalized by 1000 in order to reflect the marginal impact of a typical, i.e. ten basis point change in $S E C^{G A B}$ or $S E C^{N A B}$.

\section{Baseline regression:}

$$
\Delta \widetilde{c}_{t}^{k}=\beta_{0} \Delta \widetilde{g d p_{t}^{k}}+\beta_{1} S E C_{t}^{X, k} \times \Delta \widetilde{g d p_{t}^{k}}+\gamma_{1} S E C_{t}^{X, k}+\alpha+\delta^{k}+\tau_{t}+\varepsilon_{t}^{k}
$$

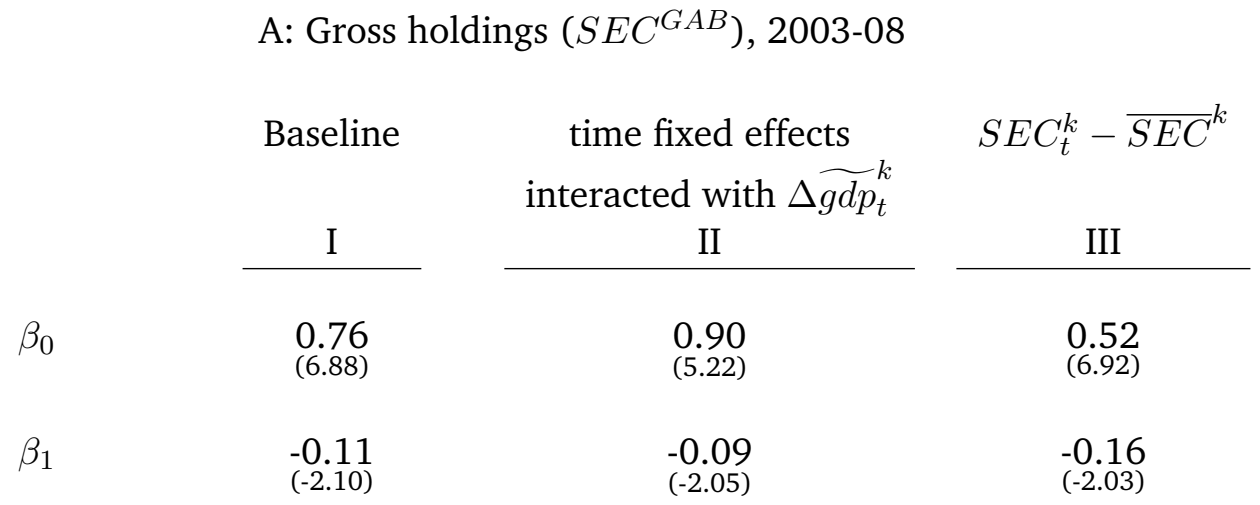

\begin{tabular}{|c|c|c|c|}
\hline & I & II & III \\
\hline$\beta_{0}$ & $\begin{array}{l}0.74 \\
(7.16)\end{array}$ & $\begin{array}{l}0.90 \\
(4.39)\end{array}$ & $\begin{array}{l}0.53 \\
(7.18)\end{array}$ \\
\hline$\beta_{1}$ & $\begin{array}{l}-0.13 \\
(-3.14)\end{array}$ & $\begin{array}{l}-0.11 \\
(-3.05)\end{array}$ & $\begin{array}{l}-0.25 \\
(-3.47)\end{array}$ \\
\hline
\end{tabular}

B: Net holdings $\left(S E C^{N A B}\right), 2003-08$ 
Table 3: Financial integration and securitization

This table presents estimates from the regression

$$
\Delta \widetilde{c}_{t}^{k}=\beta_{0} \Delta \widetilde{g d p}_{t}^{k}+\mathbf{z}_{t}^{k \prime} \beta_{z} \Delta \widetilde{g d p_{t}^{k}}+\mathbf{y}_{t}^{k \prime} \gamma+\alpha+\delta^{k}+\tau_{t}+\varepsilon_{t}^{k}
$$

with the parameterization

$$
\mathbf{z}_{t}^{k \prime} \beta_{z}=\beta_{1} S E C_{t}^{X, k}+\beta_{2} g f a_{t}^{k}
$$

and where $\mathbf{y}_{t}^{k}$ stacks those elements of $\mathbf{z}_{t}^{k \prime}$ that vary across both time and country, $g f a_{t}^{k}=\frac{\left(F A_{t}^{k}+F L_{t}^{k}\right)}{G D P_{k t}}$ with $F A_{t}^{k}$ foreign assets and $F L_{t}^{k}$ foreign liabilities of country $k$ at time $t$. Robust t-statistics (clustered by country) appear in parentheses below the estimates. $X=G A B, N A B$ stands for the various securitization measures. Coefficients on $S E C^{G A B}$ and $S E C^{N A B}$ are normalized by 1000 in order to reflect the marginal impact of a typical, i.e. ten basis point change in $S E C^{G A B}$ or $S E C^{N A B}$. Data on foreign assets and liabilities are from Lane and Milesi-Ferretti (2007) and run till 2007. Since the regressions cover the period 2003-08, $g f a_{t}^{k}$ for 2008 has been extrapolated from a 4th-order polynomial previously fitted to the data.

\begin{tabular}{ccc}
\multicolumn{3}{c}{ interaction of $\widetilde{\Delta g d p_{t}^{k}}$ with } \\
1 & $S E C_{t}^{X, k}$ & $g f a_{t}^{k}$ \\
$\left(\beta_{0}\right)$ & $\left(\beta_{1}\right)$ & $\left(\beta_{2}\right)$ \\
\hline
\end{tabular}

A: Gross holdings: $\left(S E C^{G A B}, 2003-2008\right)$

$\begin{array}{lll}0.66 & -0.12 & 0.02 \\ (4.26) & (-2.78) & (1.02)\end{array}$

B: Net holdings: $\left(S E C^{N A B}, 2003-2008\right)$

$\begin{array}{lll}0.60 & -0.15 & 0.03 \\ (4.00) & (-5.94) & (1.62)\end{array}$


Table 4: Risk sharing, securitization and credit

The table presents regressions of the form

$$
\Delta \widetilde{c}_{t}^{k}=\beta_{0} \Delta \widetilde{g d p}_{t}^{k}+\mathbf{z}_{t}^{k \prime} \beta_{z} \Delta \widetilde{g d p}_{t}^{k}+\mathbf{y}_{t}^{k \prime} \gamma+\alpha+\delta^{k}+\tau_{t}+\varepsilon_{t}^{k}
$$

where $\mathbf{z}_{t}^{k \prime} \beta_{z}=\beta_{1}\left(\frac{\text { credit }}{G D P}\right)_{t}^{k}+\beta_{2} S E C_{t}^{X, k}+\beta_{3}\left(\frac{c r e d i t}{G D P}\right)_{t}^{k} \times S E C_{t}^{X, k}+\beta_{4} t$ and where $\mathbf{y}_{t}^{k}$ stacks those elements of $\mathbf{z}_{t}^{k \prime}$ that vary across both time and country. The sample period is 2003-2008. Robust $t$-statistics (clustered by country) appear in parentheses. Coefficients on $S E C^{G A B}$ and $S E C^{N A B}$ are normalized by 1000 in order to reflect the marginal impact of a typical, i.e. ten basis point change in $S E C^{G A B}$ or $S E C^{N A B}$. Trend coefficient $\left(\beta_{4}\right)$ not reported.

\begin{tabular}{lccc}
\multicolumn{3}{c}{ interaction of $\Delta \widetilde{g d p}_{t}^{k}$ with } & \\
1 & {$\left[\frac{c r e d i t}{G D P}\right]_{t}^{k}$} & $S E C_{t}^{X, k}$ & {$\left[\frac{c r e d i t}{G D P}\right]_{t}^{k} \times S E C_{t}^{X, k}$} \\
$\left(\beta_{0}\right)$ & $\left(\beta_{1}\right)$ & $\left(\beta_{2}\right)$ & $\left(\beta_{3}\right)$ \\
\hline
\end{tabular}

A: Credit alone

$\begin{array}{ll}0.08 & 0.31 \\ (0.23) & (1.27)\end{array}$

B: Credit and Gross holdings: $\left(S E C^{G A B}, 2003-08\right)$

$\begin{array}{llll}1.15 & 0.52 & -0.12 & \\ (7.19) & (2.96) & (-2.48) & \\ 1.20 & 0.84 & -0.19 & -0.18 \\ (4.87) & (3.10) & (-2.77) & (-1.91)\end{array}$

C: Credit and Net holdings: (SEC $\left.C^{N A B}, 2003-08\right)$

$\begin{array}{llll}1.14 & 0.55 & -0.15 & \\ (7.45) & (3.05) & (-3.11) & \\ 1.22 & 0.83 & -0.24 & -0.18 \\ (6.11) & (4.58) & (-5.39) & (-3.45)\end{array}$


Gross holdings (SEC $\left.C^{G A B}, 2003-08\right)$

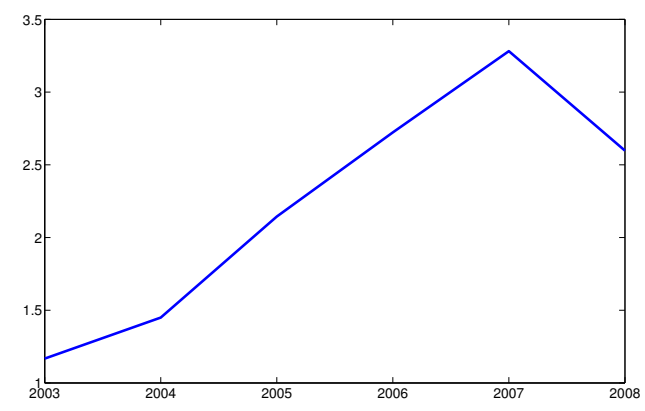

Figure 1: The figure shows the cross-country averages of the securitization indicator, $S E C_{t}^{G A B, k}$ that is based on cross-border gross holdings of ABS (as percent of joint (US and home) GDP $\times 10$ ). 


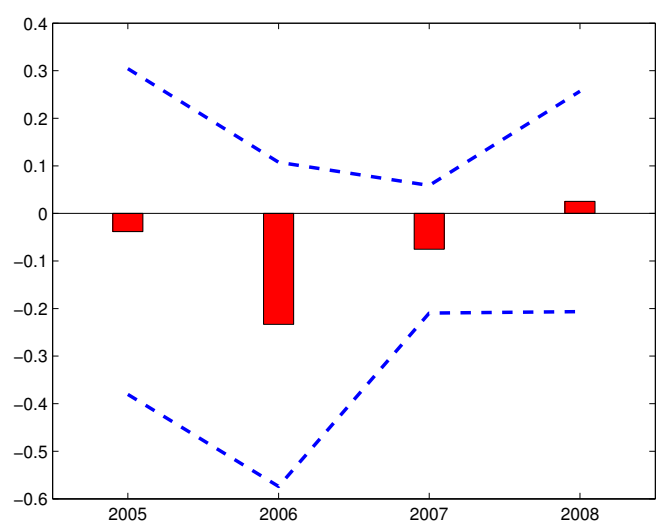

Figure 2: Marginal impact of securitization on international risk sharing 2005-08. The red bars indicate the marginal effect on the conditional volatility of country-specific consumption growth in the respective year, i.e. the coefficient $\beta_{1}(t)$ in $\Delta \widetilde{c}_{t}^{k}=\beta_{0}(t) \Delta \widetilde{g d p_{t}}+\beta_{1}(t) \times S E C_{t-1}^{G A B, k} \times \Delta \widetilde{\Delta d p_{t}}+$ $\tau_{t}+\varepsilon_{t}^{k}$. The blue (dashed) lines indicate the $95 \%$ confidence intervals. 